Island Studies Journal, Vol. 2, No. 2, 2007, pp. 177-192

\title{
The Quarantine Protection of Sub-Antarctic Australia: Two Islands, Two Regimes
}

\author{
Sandra Potter \\ School of Geography and Environmental Studies \\ University of Tasmania, Australia \\ s_potter@utas.edu.au
}

\begin{abstract}
Sub-Antarctic Heard Island and Macquarie Island are among Australia's offshore properties susceptible to colonization by species introduced by humans. While both islands share World Heritage status and are IUCN Category Ia Protected Areas (Strict Nature Reserves), different quarantine protection regimes are in operation. Macquarie Island's biosecurity appears to be less catered for while the means and likelihood of introductions are greater. The administrative, political, practical and geographical contexts within which quarantine management planning takes place variously impact on the level of quarantine protection provided to both islands. These and other remote sites of high conservation value are unlikely to receive heightened protection until the issues associated with such management contexts receive greater attention.
\end{abstract}

Keywords: island studies, protected areas, conservation, invasive species, aliens, biosecurity, Heard Island, Macquarie Island, Australia

Copyright @ 2007 Institute of Island Studies, University of Prince Edward Island, Canada.

\section{Introduction}

The international significance of islands to biodiversity conservation is widely acknowledged; so is the special vulnerability of endemic island biota to the impact of introduced species (Loope, 1992; US Congress, 1993; D’Antonio \& Dudley, 1995; McNeely, 2004). Geographically remote and or evolutionarily isolated islands are at particular risk (SSC, 2000). Recognizing these concerns, the Convention on Biological Diversity's Conference of Parties calls upon signatories to establish quarantine barriers to protect islands within their nation states from the entry of species that could, amongst other things, damage island ecosystems and induce biodiversity loss (CBD, 2006).

A review of the literature establishes that much research attention has been given to predicting likely 'alien invaders' and the environmental impacts of species introduced: such as Biological Invasions, a journal dedicated to the subject. However, comparatively few studies have focused on the design and administration of quarantine management systems and the implications of such factors on the ground (but see McAusland \& Costello, 2004; Perrings et al., 2005; Nerlich \& Wright, 2006; Stokes et al., 2006). In this paper, I consider the means by which Australia's sub-Antarctic islands and their surrounding islets, offshore rocks and shoals are notionally protected from human- 


\section{S. Potter}

facilitated introductions of non-indigenous species. I describe how species and material of quarantine concern may be introduced to these sites - including by the agencies tasked with providing for the islands' protection - and the quarantine controls in place as at June 2007. Then, using information obtained by way of stakeholder interviews conducted between April 2006 and January 2007, personal observations, and examining management plans and agency records, I identify and discuss issues of significance to the islands' quarantine integrity.

\section{Sub-Antarctic outposts}

Heard Island $\left(53^{\circ} 06^{\prime} \mathrm{S}, 73^{\circ} 31^{\prime} \mathrm{E}\right)$ lies in the Indian Sector of the Southern Ocean, some $1,000 \mathrm{~km}$ north of Antarctica and 4,000 km south-west of Australia. It is a heavilyglaciated land mass approximately $43 \mathrm{~km}$ long and $25 \mathrm{~km}$ in diameter. Its highest point is $2745 \mathrm{~m}$ above sea level. The island's wildlife includes migratory birds and marine mammals listed under four international conservation agreements, and species listed as endangered or vulnerable under Australian environment protection legislation. The Territory of Heard Island and McDonald Islands was inscribed on the World Heritage List in 1977 on account of its outstanding natural universal values. Heard Island also forms part of a Commonwealth Marine Reserve managed by the Australian Antarctic Division (AAD) of the Australian Government Department of the Environment and Water Resources, acting under delegation from the Director of National Parks. The Marine Reserve was

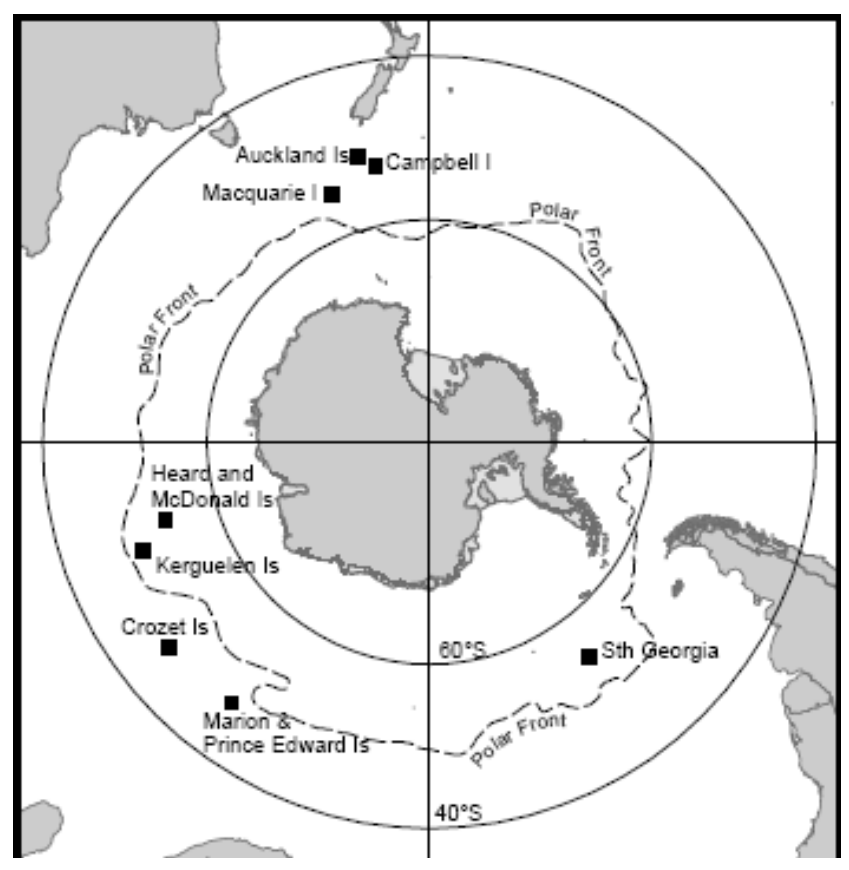
declared in 2002 and is, in its entirety, an IUCN Category Ia Protected Area of $65,000 \mathrm{~km}^{2}$. The terrestrial component has been managed as a Category Ia site since 1996.

Figure 1: Islands of the sub-Antarctic (Source: Australian Antarctic Division, Australian Antarctic Data Centre: (c) Commonwealth of Australia. Reproduced with permission).

In the vastness of the Southern Ocean (Figure 1), Heard Island is relatively close to the Kerguelen Islands (France), which are heavily impacted by introduced species (Gaucel et al., 2005). Heard Island is however littlevisited. In the absence of infrastructure typical of other Australian ports, personnel access and cargo discharge is by helicopters, inflatable rubber boats, amphibious craft and workboats. Usually two or three authorized landings of typically two or three hours' duration are made each year and it is plausible that unreported, unauthorized landings are made there from time to time. Scientific expeditions, of which there have been two in the last decade, involve the establishment and occupation of campsites for two or three months at a time. 
While the first people landed on Heard Island in 1855, it was perhaps not until 1952 that the first intentional but transient human-facilitated introduction of non-indigenous species took place. Concerted effort was involved: 24 Border Leicester sheep transported aboard the Tottan were moved to the wings of the ship's bridge after their wooden pens were demolished by waves (Law, 1983). Despite these efforts, unlike most other sub-Antarctic islands for which numerous introduced species are recorded (see review by Frenot et al., 2005), only four 'aliens' ${ }^{1}$ are known to have established - thrips Apterothrips apteris, mites Tyrophagus putrescentiae, earthworms Dendrodrilus rubidus and annual meadow grass Poa annua (AAD and Director of National Parks, 2005). Because of Heard Island's near alien-free status, its negligible alteration by humans, and the conservation values ascribed to the Territory, the prevention of introductions associated with human activity is a major factor in management considerations (AAD and Director of National Parks, 2005). A specified aim of the island's management is:

"To prevent the human introduction into the Reserve of alien species or disease and to respond to reports of such events to minimize impacts on the Reserve's values" (AAD and Director of National Parks, 2005:49).

Macquarie Island (54³0'S, $158^{\circ} 57^{\prime} \mathrm{E}$ ) is not as isolated, lying some $1500 \mathrm{~km}$ south-east of Tasmania and $600 \mathrm{~km}$ south-west of the Auckland Islands (New Zealand) on a wellestablished sub-Antarctic cruise ship route. The island is $34 \mathrm{~km}$ long and $5.5 \mathrm{~km}$ at its widest point, and has steep coastal slopes flattening out mostly some $200-300 \mathrm{~m}$ above sea level. Macquarie Island is listed as habitat critical to the survival of wandering albatrosses Diomedea exulans and grey-headed albatrosses Thalassarche chrysostoma and is home to numerous other threatened species. It is also the site of a continuously-occupied Australian Government research station supporting the Australian Antarctic Program (AAP) and accommodating up to 40 scientists, support staff, meteorologists and park rangers.

Macquarie Island is a Tasmanian (State) Nature Reserve administered by the Director of the Parks and Wildlife Service (PWS) of the Department of Tourism, Arts and the Environment. The island and its surrounds within a 12 nautical mile radius were inscribed on the World Heritage List in 1997. In addition, the island and its surrounds to 3 nautical miles are a restricted area under the National Parks and Reserves Management Act 2002. On its eastern side, the Reserve is abutted by a 1999-proclaimed Commonwealth marine park (IUCN Protected Area, Categories Ia and IV).

\footnotetext{
1 “At HIMI [Territory of Heard Island and McDonald Islands], an alien species is defined to be a species, subspecies or lower taxon that has been introduced to the HIMI Marine Reserve as a result of human activity in or around the Reserve, or that has arrived in the Reserve by natural means from an area to which it was introduced as a result of human activity. This means that an alien is a new species that arrives at HIMI having been directly transported there by human activities (in someone's pocket, or on equipment), or having arrived by natural processes (such as wind, seabirds) from a location to which it had been introduced by humans (e.g. from another subantarctic island group)" (AAD, 2006: unpaginated).
} 


\section{S. Potter}

There are approximately eight ship and yacht visits to Macquarie Island each year and most are associated with tourism. An annual limit of personnel landings is set at 750 (PWS, undated), although between 1990-91 and 2004-05 the average annual number of visitors was 334 (Kriwoken et al., 2006).

Macquarie Island has long-received numerous human-assisted introductions, mostly by sealing gangs operating in the 1800s and early 1900s, including rabbits in 1879 (Cumpston, 1968:118). Also imported have been cats, rats, mice, wekas, sheep, goats, cows, horses, donkeys, pigs, ducks and geese. There are five alien plant species recorded in the reserve; chickweed Cerastium fontanum and Stellaria media, curled dock Rumex crispus, sweet vernal Anthoxanthum odoratum and annual meadow grass Poa annua. Three of these are deemed common and widespread. All are recorded as being present on account of human activity (PWS, 2006). The island's remaining introduced vertebrates rabbits Oryctolagus cuniculus, rats Rattus rattus and mice Mus musculus - threaten the island's native biodiversity (Brothers et al., 1982; Copson \& Whinam, 2001; PWS, 2006). A key reserve management objective is:

"To prevent further accidental introductions of alien plant species or fauna and to eradicate or control, as far as possible, previously introduced species that affect or endanger native species and habitats” (PWS, 2006:49).

The very significant impacts already caused by introduced species (see PWS, 2007), the cost of cat eradication at US\$2.3 million in 2000 (Martins et al., 2006), and the forecast cost of a rabbit and rodent eradication program due to commence in 2009 (at US\$20 million) give weight to the importance of quarantine arrangements, and their review.

\section{Local Frameworks for Protection}

Heard Island's quarantine protection is provided for by a territory-specific instrument: the Environment Protection and Management Ordinance (EPMO) 1987, and a management plan prepared under the (Cwth) Environment Protection and Biodiversity Conservation (EPBC) Act 1999. The relationship between the Ordinance and the Act is described thus:

"[T]he provisions of the EPMO apply to and govern a broader range of activities and conduct than the EPBC Act or the EPBC Regulations do. As such, the EPMO can allow for more comprehensive protection of the Reserve and its values. For example, unlike the EPBC Act or EPBC Regulations, the EPMO imposes a broad prohibition on the introduction of any 'organism' (as defined) ${ }^{2}$ [or soil] into the Territory without a permit issued under that Ordinance. It also prohibits entry to the Territory without a permit” (AAD and Director of National Parks, 2005:16).

\footnotetext{
2 "Any plant or animal; or any virus, bacterium or yeast, alive or dead” (s. 4). And while 'take' (from the Territory) is defined, 'introduce' is not.
} 
Macquarie Island's quarantine protection is provided for in particular by the (Cwth) Quarantine Act 1908 which constrains imports to Macquarie Island by virtue of constraining imports to Australia generally, the Tasmanian Nature Conservation Act 2002, a management plan prepared under the Tasmanian National Parks and Reserves Management Act 2002, and measures proposed and implemented by the AAD or its contractors. These measures are underpinned by a set of quarantine management guiding principles detailed in Potter and Maggs (in press).

For both islands, the EPBC Act also has bearing with respect to matters deemed to be of national environmental significance. These matters include the protection of World Heritage values and the protection of threatened and migratory species. If an action is likely to have a significant impact on a matter of national environmental significance, or poses a credible risk of such an impact, then the activity is required to be referred to the Australian Government Environment Minister for decision on whether approval is required, and his or her determination on the environmental impact assessment process that is to be followed.

\section{Practical Mitigation against Introductions}

Quarantine measures specified in management plans and aimed at minimizing humanfacilitated introductions to Heard Island and Macquarie Island are listed at Table 1. Measures prescribed for Heard Island but not Macquarie Island include a ban on the landing of eggs and poultry meat; a ban on landing untreated timber; restrictions on routing to the island from ports outside Australia; and a ban on wearing ashore outer clothing previously used elsewhere. Additional measures specific to and selectively applied across AAP operations are listed at Table 2.

Macquarie Island's management plan makes provision for the conduct of a number of activities precluded at Heard Island. Those activities having quarantine implications include air drops, the cultivation of vegetables, track making, and the development of infrastructure associated with tourism. Air drops require specific prior authorization while proposals involving landscape modification are required to be assessed by way of a process set out in the 'Tasmanian Reserve Management Code of Practice'. For hydroponics, the permit issued by the Parks and Wildlife Service stipulates the use of a dedicated facility; the use of expanded clay as the growing medium; that only vegetables and herbs are to be grown; plants must not be allowed to grow to seed; and nutrient waste is to be repatriated to the Tasmanian mainland (AAD, 2005). Notwithstanding the criticisms past AAP hydroponic operations have attracted (Greenslade, 1987; AAD, 1994), when operating within the permit controls, hydroponics are viewed by the land manager as a means of reducing the risk of introductions on account of the mooted reduction in the fresh produce procured for shipment to the island (PWS, 2006). 


\section{S. Potter}

Table 1: Comparing management plan-prescribed quarantine-related controls and measures.

\section{Quarantine Measure}

Access authority/permit to make landings

Restrictions on sites at which landings may be made

Previous port of call to be Australian/AQIS controlled

Authorised official to accompany any visit to ensure compliance with quarantine requirements

Authorised official to be present at ship departures to ensure

compliance with quarantine requirements

Ban on ballast water discharge within $12 \mathrm{~nm}$

Actions to ensure ships' freedom from hull fouling

Application of anti-foulants

Requirement for ships to have Deratting Certificate or Deratting

Exemption Certificate

Inspection for rodents conducted on day of departure

Laying of rodent baits and traps on ships

Shipboard insect trapping

Ban on ships mooring to shore

Fumigation or other approved treatment of timber

Actions to ensure cleanliness of cargo, helicopters, watercraft

Containerization of cargo during shipment, where practicable

Ban on landing of brassicas

Ban on landing of other fresh fruit and vegetables

Ban on landing of fresh fruit and vegetables from ships' stores

Ban on landing viable seeds and viable fungal products

Ban on landing poultry meat and eggs

Ban on landing live plants and animals unless specifically permitted

Ban on import of soil

Ban on taking certain food stuffs off station

Requirement for outer clothing to be new or used only at the island

Pre-landing scrubbing of footwear

Disinfection of scientific equipment in contact with animals

Controls on conduct of hydroponics

Laying of rodent baits and traps at landing area

Incineration or removal of food waste

$\begin{array}{ll}\text { Heard } & \text { Macquarie } \\ \text { Island } & \text { Island }\end{array}$

Yes

Yes

Yes $^{3} \quad$ No

$\mathrm{Yes}^{4} \quad$ No

Yes $^{4} \quad$ No

Yes

Yes $\quad$ Yes

\begin{tabular}{c|c|} 
Yes $^{1}$ & Yes $^{1}$ \\
\hline No & Yes $^{1,5}$ \\
\hline Yes & No $^{6}$
\end{tabular}

\begin{tabular}{|l|l|}
\hline Yes $^{4}$ & No \\
\hline Yes & No \\
\hline
\end{tabular}

Yes $\quad$ No

\begin{tabular}{l|l} 
Yes & Yes
\end{tabular}

\begin{tabular}{l|l} 
Yes & No
\end{tabular}

\begin{tabular}{|c|c|} 
Yes & Yes $^{1}$ \\
\hline
\end{tabular}

\begin{tabular}{l|l} 
Yes & No
\end{tabular}

\begin{tabular}{l|l} 
Yes & No \\
Yes & No
\end{tabular}

\begin{tabular}{l|l} 
Yes $^{2}$ & No
\end{tabular}

Yes $\quad$ Yes

\begin{tabular}{l|l} 
Yes & Yes \\
Yes & No
\end{tabular}

Yes $^{8} \quad$ No

Yes $\quad$ Yes

\begin{tabular}{l|l} 
Yes & Yes \\
\hline
\end{tabular}

n/a $\quad$ Yes

Yes $\quad$ No

\begin{tabular}{l|l} 
Yes & Yes
\end{tabular}

\begin{tabular}{l|l} 
Yes & No
\end{tabular}

n/a $\quad$ Yes

\begin{tabular}{l|l} 
Yes & $\mathrm{n} / \mathrm{a}^{7}$ \\
\hline
\end{tabular}

${ }^{1}$ Not routinely compliance-checked by land manager.

${ }^{2}$ Unless the land manager is satisifed that they have been effectively treated to eliminate the risk of introducing associated alien species and diseases.

${ }^{3}$ Unless exceptional circumstances means this is not feasible and the land manager is satisfied that the entry to the Territory of the vessel presents a sufficiently low risk of the introduction to the Territory of alien species or disease.

${ }^{4}$ Discretionary. 
${ }^{5}$ Implied requirement given that the land manager may require evidence of hull antifouling as a condition of access.

${ }^{6}$ Ships must be certified free of rodents since their last major port of call.

${ }^{7}$ Rodents are well-established on the island.

${ }^{8}$ Other than egg powder, or products containing egg powder, which can be taken ashore if kept in sealed containers and opened only in an enclosed shelter.

Table 2: Quarantine Controls and Measures specific to AAD/AAP Operations, and the Islands for which they are undertaken.

Quarantine Measure

\begin{tabular}{|l|c|c|}
\hline Use of quarantine approved premise for cargo consolidation & Yes & Yes \\
\hline Inspection of mail using quarantine detector dogs & n/a & Yes \\
\hline Pre-departure inspection of ship holds, galley and accommodation & Yes & Yes \\
\hline Ship cabin and baggage checks using quarantine detector dogs & Yes & Yes \\
\hline Ozone treatment of produce during transit & n/a & Yes \\
\hline Personal effects cleanliness declarations & Yes & No \\
\hline Third party hand inspection of all personal effects landed & Yes & No \\
\hline
\end{tabular}

\section{Issues in Constituting Protection}

This section discusses specific issues seen as potentially compromising the quarantine protection of Heard Island and/or Macquarie Island. Their significance emerges out of: semi-structured interviews with senior public servants (referred to below as 'stakeholders') responsible for the islands' conservation, policy development, biosecurity and/or operational logistic support; perusal of management plan prescriptions, agency-issued permits, and post-activity reports; and personal observations and experience. Although, indepth interviews with a few, carefully selected persons can provide significant insights into issues surrounding research topics (Bradshaw \& Stratford, 2000), I do not claim to have necessarily drawn out the only quarantine protection-related issues, or the most compelling.

\section{Unbridled imports}

A growing body of literature links the volume of imports to islands and the probability of introductions. Practice also suggests that quarantine management systems, no matter how rigorously designed and implemented, cannot totally guard against unintentional introductions (Nairn et al., 1996; Joint Committee of Public Accounts and Audit, 2003; Wittenberg \& Cock 2005; author's observations). For Heard Island, a management plan prescription seeking to address this concern advocates that "the quantity of material to be taken ashore in the Reserve should be minimized to the greatest extent practicable" (AAD and Director of National Parks, 2005:71). 


\section{S. Potter}

Even programs declared to be small scale, minimalist or low impact and intended to contribute to island protection can entail the landing of considerable volumes of cargo that may undermine the islands' biosecurity. For example, in support of the 2000-01 summer AAP campaign to Heard Island, 76 pallets and crates, 17 huts, 20 gas bottles, 131 drums of fuel, $2590 \mathrm{~kg}$ of personal effects and equipment, and 50 cartons of perishable food were landed via some 230 ship-shore helicopter sorties (unpublished AAD records). In support of standard Macquarie Island programs, some $500-900 \mathrm{~m}^{3}$ of cargo are typically shipped to the island each year: volumes that have provided for the inadvertent landing of seeds and other plant material, and one or more live tree frogs, spiders, slaters, snails, ants, cockroaches, wasps, beetles and weevils (Potter, 2006; unpublished AAD records). Incursions such as these, however, are reported with diminishing frequency as quarantine protocols are continuously reviewed and improved (unpublished AAD records).

Stakeholders questioned on the adoption of material-minimizing actions in relation to imports to Heard Island and Macquarie Island considered that such an agenda was unlikely to be embraced. A reason offered was that for sub-Antarctic operations, contingency planning is all-important in light of the few resupply opportunities: 'over catering' can become a norm. Also suggested was that the rigours of life on these remote outposts can generate a demand for material comforts by way of compensation for social deprivations; hence the shipment of more cargo. A stakeholder involved in the shipping support of AAP operations at both islands noted that the volume of materials imported thus far has been constrained only by the cargo space available on the ships chartered to deploy parties, and by unfavourable weather and sea conditions over the period allocated for cargo discharge.

While at some sites of high conservation value it is deemed appropriate to place controls on the number of personnel landings that may be made (Macquarie Island included) and the number of individuals that may be ashore at any one time, limits are rarely placed on how much cargo may be landed at such sites. For instance, at Barrow Island, a 23,438 ha 'A-Class Nature Reserve' off the coast of Western Australia, an estimated three million tonnes of industrial freight will most likely be landed (R. Stoklosa, consultant to ChevronTexaco, personal communication, 2007).

\section{Conflicting interests: operational versus environmental policy}

As administrator of the Territory of Heard Island and McDonald Islands, the AAD selfregulates its programs there, raising the potential for conflicts of interest with respect to the priority given to environmental management activities. Kriwoken et al. (1989:16-17) submit that:

"The role of protagonist of operations, with its pressure to cut corners in the interests of (say) efficiency, ease and maintenance of [shipping] schedules, and the role of implementer and enforcer of environmental 'thou shalt nots', inevitably conflict, and, in the absence of any watchdog over the watchdog, it is to be expected that such conflicts will often be resolved in favour of operational interests rather than the interest of the executor of environment policy interests. ... Under 
such conditions, operational concerns will frequently triumph at the expense of environmental priorities.”

Actions that lend weight to Kriwoken et al.'s claim include the authorization of the local disposal of food scraps and human waste, and the delayed repatriation of other wastes stockpiled on the island at the end of the 2004 AAP campaign. A stakeholder identified occasions when scientific equipment evaded pre-departure quarantine procedures on account of its late availability for loading, and when cargo was unable to be containerized and fumigated in line with standard operating procedures. While these departures from procedure were managed in such a way that the cargo involved presented negligible quarantine risk (author's observation), scenarios such as these are indicative of the introduction of flexibilities that could lead to inadvertent introductions.

Indeed, the Australian Government has considerable discretion to act, or not act, on Heard Island protection issues including those related to quarantine. The text of the Reserve's management plan includes considerable non-committal language. Thus the Director of the AAD may rather than will take various courses of action. The implementation of management plan prescriptions is also subject to funding availability (AAD and Director of National Parks, 2005).

Implementation of the prescriptions in the Macquarie Island plan is similarly qualified, being "subject to the provision of funding and other resources sufficient to meet them, and may be prioritized by the Director of National Parks and Wildlife at the Director's discretion according to resource availability" (PWS, 2006:132). And, while the Parks and Wildlife Service self-regulates its activities on Macquarie Island, there is greater potential for third party scrutiny than occurs at Heard Island on account of the concurrent presence of personnel from other agencies, greater tourist visitation, and the Parks and Wildlife Service's use of the AAD's facilities.

\section{Ship fouling mitigation}

Sub-Antarctic shipping provides for the transport of marine species via ballast water discharge and fouling (Lewis et al., 2005). Lewis and Summerson (2005:40) consider that "vessels residing in port regions for long periods, especially those vessels without antifoulant or with incomplete antifoulant protection, represent a major risk of translocating invasive marine species" to the region. A seaweed Undaria, introduced to New Zealand around 1987, was recently discovered in waters around that country's subAntarctic islands (DOC, 2006).

While quarantine protocols for ships entering the Macquarie Island Nature Reserve's 3 nautical mile outer boundary are under development (PWS, 2006:97), various hull fouling management measures have been recommended for ships likely to operate in the Macquarie Island Marine Park (see Lewis \& Summerson, 2005). For the ships assessed as representing the highest quarantine threat the measures proposed include in-water hull cleaning, annual dry-docking, and off-season lay-up in fresh water. These measures are either unlikely to be authorized (see ANZECC, 2000) or are unlikely to be acceptable to 


\section{S. Potter}

operators and ship owners on account of the costs and (im)practicalities (G. Dannock, AAD Shipping \& Air Operations Manager, personal communication, 2006).

Currently, an implied Parks and Wildlife Service requirement is the application of antifoulant to ships entering within 3 nautical mile of the island (as opposed to hull cleanliness per se). ${ }^{3}$ Invocation of this requirement would constrain the use of the icebreaker presently chartered by the AAD to resupply its station, and could leave the Parks and Wildlife Service with few if any other means of (free) island access for land management purposes. The level of protection provided to Macquarie Island's near-shore environment could therefore be weakened by any unwillingness, on the part of the Parks and Wildlife Service, to 'bite the (AAD) hand that feeds it.'

While the Heard Island management plan specifies that ship hulls "must be cleaned or treated to minimize the risk of marine introductions from fouling species" (AAD and Director of National Parks, 2005:70), compliance with this requisite has yet to be verified (Potter, 2006).

\section{Provisions for international shipping}

Despite Macquarie Island's designation as an IUCN Category Ia Protected Area, and although the island is not a proclaimed 'first port of entry' into Australia under the Commonwealth's Quarantine Regulations 2000 (or permitted entry point for plant material under the Tasmanian Plant Quarantine Act 1997), landings are permitted from ships originating from ports outside Australia. Some of these ships transport Parks and Wildlife Service personnel to the island gratis or at reduced fares. Indeed, a criterion used in the selection of tourist vessels to be granted island access is "benefits to the [island's] management and protection ... for instance, assistance with programs, or with transport of equipment and personnel" (PWS, 2006: 111). Paradoxically, the use of tourist ships to transport AAD/AAP personnel to the island is identified by the Parks and Wildlife Service as being a cause of concern (PWS, 2006: 98).

In contrast, landings at Heard Island may only be made from ships that have departed Australian ports where pre-departure quarantine protection activities can be readily monitored by the AAD, unless exceptional circumstances mean this is not feasible and the ship's visit is deemed to present a low risk of introductions (AAD and Director of National Parks, 2005).

On arrival at Macquarie Island, ships from overseas are granted partial pratique by a member of the AAD's staff appointed as a temporary quarantine officer under the Quarantine Act 1908. This concession exists despite there being limited on-site capacity to respond to any landings of contaminated materials or to manage disease events (author's observation), and despite the high quarantine risks believed to be associated with sequential sub-Antarctic landings. Possibly, as many as half of the ships visiting

\footnotetext{
3 "The Director may require evidence of hull anti-fouling as a condition of access authorization of access (sic) to the reserve" (PWS, 2006:98).
} 
Macquarie Island route via New Zealand's sub-Antarctic islands.

\section{The tyrannies of isolation and remoteness}

Stakeholders noted the potential for isolation and remoteness to negatively impact on island quarantine protection, their views providing counterbalance to the argument that these island may be 'naturally protected' by their geographies. Among issues identified for one or both islands were: the need for heavy reliance on third party biosecurity protocols and agreements to achieve quarantine goals; likely delays in detecting introductions; a likely inability to control or eradicate species by the time they are discovered; reduced capacity for quarantine management workloads to be shared; the aforementioned limited availability of on-site resources for quarantine incursion or disease response; and the existence of 'out of sight, out of mind' attitudes. The last aspect was presented as having both positive and negative aspects in terms of land managers' activities not being subject to the usual levels of public scrutiny, versus the challenge of generating enthusiasm and support for the protection of an island that only a privileged few are able to visit.

Island research: a little-explored threat?

IUCN Category Ia Protected Areas are valued as sites for monitoring, baseline studies, research into the functioning of ecosystems, and the conservation of biodiversity. A qualifier on their use nevertheless applies: "The responsibility to understand and study protected and environmentally sensitive areas must not take precedence over our primary obligation: to protect and care for them" (ASTEC, 1998:1). Notwithstanding this ideal, stakeholders noted the absence of robust mechanisms by which land mangers could assess the environmental impacts potentially associated with the conduct of island-based research against the likely contributions of the research to the islands' conservation. There may also be little incentive for researchers to draw attention to the potential of their activities to result in the introduction of species, a disincentive being the possible withdrawal or curtailing of the research community's island access privileges.

While the quarantine risks presented by scientific programs at Heard Island and Macquarie Island have not been quantified, they have nevertheless been identified, by stakeholders, as being a significant management concern. A 2003-conducted survey of the clothing and footwear of 46 personnel on a sub-Antarctic plying tourist vessel gives weight to the nomination of researchers as a potential source of introductions to the sub-Antarctic region. Of the 344 propagules collected during the survey, the greatest number was associated with the field scientists on board (Selkirk, 2006). The quarantine threats associated with research have also been touched upon in an unpublished risk assessment commissioned by the AAD, and research undertaken by Whinam et al. (2005).

\section{Quarantine governance complexities}

Several agencies have multiple roles in the islands' quarantine protection. For example, under a memorandum of understanding arrangement, Quarantine Tasmania officers undertake inspection and surveillance functions for AAP voyages to both islands on behalf 


\section{S. Potter}

of the AAD; as a condition of permits issued by the AAD to other Commonwealth agencies chartering ships sailing to Heard Island, Quarantine Tasmania undertakes audits of pre-departure processes; Tasmanian quarantine officers undertake national (Australian Quarantine and Inspection Service) quarantine border functions in Tasmania and by implication at Macquarie Island; in practice, the station medical officer (an Australian Government employee) undertakes national border functions on Macquarie Island; and the station leader and the Parks and Wildlife Service's ranger-in-charge are locally responsible for environmental management activities. (The arrangements at Heard Island are less complex as the Territory of Heard Island and McDonald Islands, and Australian Antarctic Territory, are excluded from the Quarantine Act 1908 and its associated instruments.)

Stakeholders, including a quarantine official, commented that establishing 'who is responsible for what' in relation to Macquarie Island was a challenge. Indeed, the absence of clarity and shared understanding in some areas has impacted upon monitoring compliance with management plan prescriptions - see Lewis et al. (2006) for results of a monitoring oversight - and the timely delivery of quarantine protection messages (author's observations). Island governance issues also extend beyond the quarantine barrier: State and Commonwealth ministers have recently been locked in a protracted debate over the provision of funding for the eradication of the island's rabbit and rodent population (e.g.: Maiden, 2006; Australian Government, 2007; Turnbull, 2007).

While beyond the scope of this paper, the potential for Macquarie Island to be a source of 'reverse' quarantine threats to other parts of Tasmania and the Australian mainland has so far been little-considered (but see Greenslade et al., 2007 with respect to the potential translocation of flatworm Arthurdendys vegrandis). Marine debris, including drums and containers filled with unknown substances (RPDC, 2005:43), and other soil-sullied materials are shipped each year from the island to the Tasmanian mainland. Because these shipments are intra-state movements, there are few if any administrative impediments or quarantine barrier controls in operation (author's observation). In apparent contradiction, the shipment of wastes from the Antarctic to Australia is regarded by the Australian Quarantine and Inspection Service as a high risk activity for which authorization is difficult if not impossible to obtain (G. Dannock, AAD Shipping \& Air Operations Manager, personal communication, 2006). Currently at issue is the import of kitchen scraps made up from produce originally shipped to Antarctica from Australia, and the import of material mixed with Antarctica's near ahumic 'soil' (T. Maggs, AAD Environmental Policy \& Protection Manager, personal communication, 2007).

\section{Summary and Concluding Remarks}

A suite of practical mitigation measures underpinned by varying protected area and quarantine management instruments, and a precautionary approach, provide for some controls on the introduction of species, soil, and other material of quarantine concern to Heard Island and Macquarie Island. By identifying issues of relevance to the arrangements currently contributing to the quarantine protection of these sub-Antarctic properties, this research highlights the need to give due consideration to the administrative, political, practical and geographical contexts in which quarantine management planning occurs. The 
heightened protection of these and other islands of high conservation is unlikely to be advanced until the implications of such factors are fully explored.

\section{Acknowledgements}

I thank staff of the Australian Government Department of the Environment and Water Resources; Tasmanian Government Departments of Tourism, Arts and the Environment and of Primary Industry and Water; and University of Tasmania for their contributions. In particular, I thank Andrew Jackson, Michael Lockwood, Virginia Mudie and Elaine Stratford for valued comments on an early draft. Unpublished Australian Antarctic Division records have been referenced with permission. The research underpinning this paper was approved by the Human Research Ethics Committee (Tasmania) Network.

\section{References}

AAD (1994) Initial Environmental Evaluation of the Proposal to Introduce Hydroponic Operations at Australian Antarctic Stations. 19 December 1994, amended 2 October 1998. Kingston, Australia, Australian Antarctic Division.

AAD (2005) Hydroponics Manual 05/06 Season. Kingston, Australia, Australian Antarctic Division.

AAD (2006) 'Heard Island and McDonald Islands' Australian Antarctic Division, 28 April 2007, www.heardisland.aq/.

AAD \& Director of National Parks (2005) Heard Island and McDonald Islands Marine Reserve Management Plan. Kingston, Australia, Australian Antarctic Division.

ANZECC (2000) ANZECC Code of Practice for Antifouling and In-Water Hull Cleaning and Maintenance. Department of the Environment and Heritage, 28 April 2007, www.deh.gov.au/coasts/ pollution/antifouling/code/pubs/code.pdf.

ASTEC (1998) Environmental Research Ethics: National Principles and Guidelines for the Ethical Conduct of Research in Protected Areas and Environmentally Sensitive Areas. Canberra, Australian Science, Technology and Engineering Council.

Australian Government (2007) Interview with ABC Tasmania on Macquarie Island Rats and Rabbit Eradication Program, www.environment.gov.au/minister/env/2007/tr27 mar07.html, 27 March.

Bradshaw, M.B. \& Stratford, E. (2000) 'On Research Design and Rigour' in I. Hay (ed.) Qualitative Research Methods in Geography, Melbourne, Oxford University Press, pp. 3749.

Brothers, N.P., Eberhard, I.E., Copson, G.R. \& Skira, I.J. (1982) 'Control of Rabbits Oryctolagus cuniculus on Macquarie Island by Myxomatosis', Australian Wildlife 


\section{S. Potter}

Research, Vol. 9, No. 3, pp. 477-485.

CBD (2006) Conference of the Parties, Decision VIII/1 Island Biodiversity, Convention on Biological Diversity Secretariat, 28 April 2007, www.biodiv.org/decisions/default.aspx?m=COP-08\&id=11013\&lg=0.

Copson, G. \& Whinam, J. (2001) 'Review of Ecological Restoration Programme on Subantarctic Macquarie Island: Pest Management Progress and Future Directions', Ecological Management \& Restoration, Vol. 2, No. 2, pp. 129-138.

Cumptson, I. (1968). 'Macquarie Island' ANARE Scientific Reports, Series A (1) Narrative, Pub. No. 93. Melbourne, Antarctic Division.

D'Antonio, C. M. \& Dudley, T.L. (1995) 'Biological Invasions as Agents of Change on Islands versus Mainlands’, Ecological Studies, Vol. 115, pp. 103-121.

DOC (2006) 'Undaria discovered in Subantarctic Islands, DOC to consider eradication', press release issued by the Department of Conservation, New Zealand, 7 December.

Frenot, Y., Chown, S.L., Whinam, J., Selkirk, P.M., Convey, P., Skotnicki, M. \& Bergstrom, D. (2005) 'Biological Invasions in the Antarctic: Extent, Impacts and Implications’, Biological Reviews, Vol. 80, No. 1, pp. 45-72.

Gaucel, S., Langlais, M. \& Pontier, D. (2005) 'Invading Introduced Species in Insular Heteorogeneous Environments’, Ecological Modelling, Vol. 188, No. 1, pp. 62-75.

Greenslade, P. (1987) 'Invertebrate conservation in the Antarctic and Subantarctic' in J.D. Majer (ed.) The Role of Invertebrates in Conservation and Biological Survey, Western Australia, Department of Conservation and Land Management, pp. 119-121.

Greenslade, P., Stevens, M.I. \& Edwards, R. (2007) 'Invasion of Two Exotic Terrestrial Flatworms to Subantarctic Macquarie Island’, Polar Biology, Vol. 30, No. 8, pp. 961-967.

Joint Committee of Public Accounts and Audit (2003) Report 394: Review of Australia's Quarantine Function, Canberra, Parliament of the Commonwealth of Australia.

Kriwoken, L.K., Hay, P.R. \& Keage, P.L. (1989) 'Environmental Policy Implementation: Sea Dumping off Sub-Antarctic Heard Island, Australia’, Maritime Studies, Vol. 48, No. 1, pp. 11-21.

Kriwoken, L.K., Ellis, C. \& Holmes, N. (2006) 'Macquarie Island, Australia' in G. Baldacchino (ed.) Extreme Tourism: Lessons from the World's Cold Water Islands, Oxford, Elsevier, pp. 193-203.

Law, P. (1983) Antarctic Odyssey, Melbourne, William Heinemann. 
Lewis, P.N. \& Summerson, R. (2005) Assessing the Risks of Invasion by Marine Pests at Macquarie Island, Canberra, Australia, Department of Environment and Heritage.

Lewis, P.N., Riddle, M.J. \& Smith, S.D.A. (2005) 'Assisted Passage or Passive Drift: a Comparison of Alternative Transport Mechanisms for Non-indigenous Coastal Species into the Southern Ocean', Antarctic Science, Vol. 17, No. 2, pp. 183-191.

Lewis, P.N., Bergstrom, D.M. \& Whinam, J. (2006) 'Barging in: A Temperate Community Travels to the Subantarctic’, Biological Invasions, Vol. 8, No. 4, pp. 787-795.

Loope, L.L. (1992) 'An Overview of Problems with Introduced Plant Species in National Parks and Biosphere Reserves of the USA' in C.P. Stone, C.W. Smith \& J.T. Tunison (eds.) Alien Plant Invasions in Native Ecosystems of Hawaii: Management \& Research. Honolulu HI, University of Hawaii, Cooperative National Park Resource Studies, pp. 3-28.

McAusland, C. \& Costello, C. (2004) 'Avoiding Invasives: Trade-related Policies for Controlling Unintentional Exotic Species Introductions', Journal of Environmental Economics and Management, Vol. 48, No. 2, pp. 954-977.

McNeely, J.A. (2004) 'The Problem of Invasive Alien Species’, Environment, Vol. 46, No. 6, pp. 17-29.

Maiden, S. (2006) 'Rabbits and rodents finally to leave Macquarie Island as Eradication Plan gets funded', www.abc.net.au/northtas/stories/s1943161.htm, 5 June.

Martins, T.L.F., Brooke, M. de L., Hilton, G.M., Farnsworth, S., Gould, J. \& Pain, D.J. (2006) 'Costing Eradications of Alien Mammals from Islands', Animal Conservation, Vol. 9, No. 4, pp. 439-444.

Nairn, M.E., Allen, P.G., Inglis, A.R. \& Tanner, C. (1996) Australian Quarantine: A Shared Responsibility, Canberra, Department of Primary Industries and Energy.

Nerlich, B. \& Wright, N. (2006) 'Biosecurity and Insecurity: The Interaction between Policy and Ritual during the Foot and Mouth Crisis', Environmental Values, Vol. 15, No. 4, pp. 441-462.

Perrings, C., Dehnen-Schmutz, K., Touza, J. \& Williamson, M. (2005) 'How to Manage Biological Invasions under Globalization', Trends in Ecology and Evolution, Vol. 20, No. 5, pp. 212-215.

Potter, S. (2006) 'The Quarantine Management of Australia's Antarctic Program', Australasian Journal of Environmental Management, Vol. 13, No. 3, pp. 185-196.

Potter, S. \& Maggs, T.M. (in press) 'Antarctic Quarantine Management: Australia's Framework and Practice.' Proceedings, non-native species in the Antarctic. Workshop held at Gateway Antarctica, University of Canterbury, Christchurch, April 2006. 


\section{S. Potter}

PWS (undated) 'Guidelines for tourist operations and visits to Macquarie Island Nature Reserve and World Heritage Area (Latitude 54 $30^{\circ}$ ' South, Longitude 158 ${ }^{\circ} 57^{\prime} \mathrm{E}$ ) 2006/2007', Hobart, Tasmania, Parks and Wildlife Service, Department of Tourism, Arts and the Environment, $10 \mathrm{pp}$.

PWS (2006) Macquarie Island Nature Reserve \& World Heritage Area Management Plan 2006, Tasmania, Parks \& Wildlife Service, Department of Tourism, Arts \& Environment.

PWS (2007) Summary of Plan for Eradication of Rabbits and Rodents on Macquarie Island, July, www.parks.tas.gov.au/publications/tech/mi_pest_eradication/summary.html.

RPDC (2005) Report on Macquarie Island Nature Reserve \& World Heritage Area Draft Management Plan 2003, Tasmania, Resource Planning \& Development Commission.

Selkirk, P. (2006) Human Impacts on the Terrestrial Systems, seminar presentation by P. Selkirk (for D. Bergstrom), International Forum on the Sub-Antarctic, Tasmania, July.

SSC (2000) IUCN Guidelines for the Prevention of Biodiversity Loss Caused by Alien Invasive Species, Gland, Switzerland, Species Survival Council Invasive Species Specialist Group, IUCN Council.

Stokes, K.E., O’Neill, K.P., Montgomery, W.I., Dick, J.T.A., Maggs, C.A. \& McDonald, R.A. (2006) 'The Importance of Stakeholder Engagement in Invasive Species Management: A Cross-Jurisdictional Perspective in Ireland', Biodiversity and Conservation, Vol. 15, No. 8, pp. 2829-2852.

Turnbull, M. (2007) 'Time for Tasmanian to show Macquarie Island the Money', media release, 22 March, www.environment.gov.au/minister/env/2007/pubs/mr22mar07.pdf.

US Congress Office of Technology Assessment (1993) Harmful Non-indigenous Species in the United States, Washington DC, US Government Printing Office.

Whinam, J., Bergstrom, D.M. \& Chilcott, N. (2005) 'Subantarctic Hitchhikers: Expeditioners as Vectors for the Introduction of Alien Organisms', Polar Biology, Vol. 121, No. 2, pp. 207-219.

Wittenberg, R. \& Cock, M.J.W. (eds.) (2001) Alien Invasive Species: A Toolkit of Best Prevention and Management Practices, Wallingford, Oxford, CAB International. 